\title{
KARAKTERISTIK ASAM LEMAK TAK JENUH DAN KOLESTEROL SOSIS DAGING KALKUN BERDASARKAN BAGIAN DADA DAN PAHA
}

\section{Unsaturated Fatty Acids and Cholesterol Characteristics of Turkey Sausage Based on Breast and Thigh Meat}

\author{
Bambang Dwiloka*, Robby Rusdiansyah, Yoyok Budi Pramono \\ Program Studi Teknologi Pangan, Fakultas Peternakan dan Pertanian, Universitas \\ Diponegoro, Semarang \\ JI. Prof. Soedarto Tembalang Semarang Jawa Tengah 50275 \\ *Penulis Korespondensi, Email: bambangdwilokaundip@gmail.com
}

\begin{abstract}
ABSTRAK
Penelitian ini dilakukan dengan tujuan mengetahui karakteristik asam lemak tak jenuh dan kolesterol olahan daging kalkun dalam produk sosis yang berbahan dasar potongan komersial karkas yang berbeda bagian yang terdiri dari dada dan paha. Percobaan yang dilakukan dalam rancangan acak kelompok (RAK) yaitu 2 perlakuan dengan 4 kali ulangan. (T1) sebagai perlakuan potongan karkas dada dan (T2) sebagai perlakuan potongan karkas paha. Parameter pertama yang diujikan adalah asam lemak tak jenuh dan parameter kedua adalah kolesterol. Hasil penelitian ini yaitu adanya perbedaan potongan komersial karkas yang dapat mempengaruhi kualitas asam lemak tak jenuh dan kolesterol sosis daging kalkun. Sosis dengan potongan komersial karkas dada dapat menurunkan kandungan kolesterol $(88.5 \%)$ dibandingkan karkas paha $(89.1 \%)$ dan memiliki kandungan asam lemak yang lebih tinggi $(63.47 \%)$ dibandingkan karkas paha (60.86\%) sehingga memberi manfaat untuk kesehatan.
\end{abstract}

Kata kunci: Dada, Kalkun, Kolesterol, Paha, Sosis

\section{ABSTRACT}

This research was conducted with the aim of knowing the characteristics of unsaturated fatty acids and cholesterol in processed turkey meat in sausage products made from commercial carcass pieces with different parts consisting of the breast and thigh. The experiment was conducted in a randomized block design (RAK) with 2 treatments with 4 replications. (T1) as a treatment of breast carcass pieces and (T2) as a treatment of thigh carcass pieces. The first parameter tested is unsaturated fatty acids and the second parameter is cholesterol. The results of this study were differences in the commercial cut of the carcass which could affect the quality of unsaturated fatty acids and cholesterol of turkey sausage. Sausage with commercial cuts of breast carcass can lower cholesterol content $(88.5 \%)$ compared to thigh carcass (89.1\%) and has a higher fatty acid content (63.47\%) than thigh carcass $(60.86 \%)$ so that it provides health benefits.

Keywords: Breast, Cholesterol, Sausage, Thigh, Turkey

\section{PENDAHULUAN}

Sosis merupakan produk restructured meat atau daging yang telah dicincang dengan ukuran lebih kecil kemudian dilakukan proses penggilingan, pencampuran bumbu serta bahan bahan tambahan lainnya sehingga terbentuk seperti adonan yang dapat dimasukkan ke dalam selongsong dan dilakukan proses pemasakan (Sofiana, 2012). Sangat diperlukannya 
bahan tambahan yang memiliki karakter dapat mengikat guna membantu membantu produk akhir selama daging melalui proses penggilingan dan pencampuran bahan. Di Indonesia, produksi sosis masih menggunakan bahan utama berupa daging unggas yaitu ayam. Hal ini dikarenakan tahun ke tahun tingkat konsumsi daging ayam mengalami peningkatan yang menunjukkan bahwa daging ayam sangat diminati oleh masyarakat. Kandungan protein dan lemak daging ayam masing-masing mencapai 18.2\% dan 25\% (Suloi et al., 2019). Hal tersebut dapat diketahui bahwa kandungan lemak pada daging ayam tergolong cukup tinggi sehingga kurang cocok dikonsumsi bagi masyarakat yang melakukan diet rendah lemak dan penderita penyakit ateroklerosis. Oleh sebab itu, unggas kalkun dapat dijadikan sebagai alternatif dalam mengkonsumsi produk hewani yang rendah lemak dan kolesterol. Bagian karkas unggas kalkun yang sering dimanfaatkan menjadi produk pangan hewani seperti sosis adalah daging kalkun.

Masyarakat kurang mengenal salah satu jenis ternak unggas kalkun dikarenakan rendahnya populasi dan kurangnya pemanfaatan hasil ternak kalkun dibandingkan dengan jenis unggas lainnya (Widiatmoko et al., 2014). Keunggulan daging kalkun dibandingkan dengan daging jenis unggas dan ternak lainnya adalah daging kalkun memiliki tinggi kandungan protein serta lebih rendah kandungan lemak dan kolesterol. Daging kalkun memiliki kandungan protein sebesar $30.5 \%$ dan kandungan lemak yang lebih rendah $11.6 \%$ (Oktasari et al., 2020). Potongan komersial karkas unggas terdiri dari beberapa bagian diantaranya sayap (wing), paha atas (thigh), paha bawah (drumstick), dada (breast) dan punggung (brisket) (Mait et al., 2019). Potongan komersial karkas bagian dada memiliki jaringan otot yang lebih banyak dibandingkan bagian paha dan sayap karena dipengaruhi oleh zat makanan yang mengandung protein sehingga memiliki daging yang lebih banyak dan empuk (Widiyawati et al., 2020). Potongan karkas bagian dada juga memiliki kandungan lemak yang rendah dibandingkan bagian potongan karkas lainnya (Straková et al., 2011). Kolesterol daging kalkun lebih rendah dibandingkan daging ayam. Potongan karkas kalkun bagian dada mengandung kolesterol $45 \mathrm{mg} / 100 \mathrm{~g}$ lebih rendah dibandingkan paha 71 $\mathrm{mg} / 100 \mathrm{~g}$ sedangkan potongan karkas ayam bagian dada mengandung kolesterol 116 $\mathrm{mg} / 100 \mathrm{~g}$ lebih rendah dibandingkan paha $127 \mathrm{mg} / 100 \mathrm{~g}$. Asam lemak tak jenuh potongan karkas kalkun bagian dada $(64.9 \mathrm{~g} / 100 \mathrm{~g})$ lebih tinggi dibandingkan paha $(63.6 \mathrm{~g} / 100 \mathrm{~g})$ (Gálvez et al., 2018).

Karakteristik asam lemak tak jenuh dan kolesterol sosis kalkun dapat dipengaruhi oleh bahan utama yang berasal dari perbedaan potongan komersial karkas yang digunakan. Perbedaan potongan komersial karkas mempengaruhi kadar asam lemak tak jenuh dan kolesterol. Kadar kolesterol produk sosis daging kalkun berhubungan erat dengan asam lemak tak jenuh. Kombinasi asam lemak tak jenuh yang tinggi dan kadar kolesterol yang rendah menjadi aman bagi kesehatan. Tingginya asam lemak tak jenuh memberikan dampak penurunan kolesterol jahat dan peningkatan kolesterol baik sehingga mencegah terjadinya penyakit aterosklerosis (Yuliantini et al., 2016). Kandungan lemak yang tinggi dapat berpotensi terhadap peningkatan kadar kolesterol (Septianggi et al., 2013).

\section{BAHAN DAN METODE}

Pelaksanaan penelitian ini pada bulan Agustus - Oktober 2020 di Laboraturium Kimia gizi Pangan dan Rekayasa Pangan dan Hasil Pertanian, Fakultas Peternakan dan Pertanian, Universitas Diponegoro Semarang serta Laboratorium Penelitian dan Pengujian Terpadu dan Laboratorium Teknologi Pangan dan Hasil Pertanian, Universitas Gadjah Mada Yogyakarta.

\section{Bahan}

Penelitian ini menggunakan bahan-bahan seperti potongan karkas kalkun (Meleagris gallopavo) segar bagian dada dan paha, tepung tapioka, air es, garam, gula, minyak nabati (mazola sunflower oil), sodium tripolyphosphate (STTP), merica, bawang putih dan selongsong plastik polyamide food grade. 
Alat

Penelitian ini menggunakan peralatan seperti timbangan analitik, Gas Chromatography (GC) (SHIMADZU), Food Processor (MITOCHIBA), Spectrofotometer, blender (PHILIPS), thermometer, pisau, baskom, talenan, kompor, panci, sendok, plastic wrap, plastik segitiga, cup, label.

\section{Desain Penelitian}

Desain yang digunakan ialah Rancangan Acak Kelompok (RAK) dimana total perlakuan adalah 2 dan 4 kali ulangan sehingga berjumlah 8 unit percobaan. Perlakuan yang digunakan adalah menggunakan perbedaan potongan komersial karkas bagian dada (T1) dan paha (T2).

Tabel 1. Rancangan Percobaan Sosis Daging Kalkun

\begin{tabular}{ccc}
\hline Ulangan & & Perlakuan \\
\cline { 2 - 3 }$(U)$ & T1 & T2 \\
\hline 1 & T1U1 & T2U1 \\
2 & T1U2 & T2U2 \\
3 & T1U3 & T2U3 \\
4 & T1U4 & T2U4 \\
\hline
\end{tabular}

Keterangan: $\mathrm{T} 1=$ Dada dan T2 $=$ Paha

\section{Tahapan Penelitian}

Beberapa tahapan yang dilakukan selama proses penelitian yaitu tahap pertama adalah pembuatan sosis daging kalkun dan selanjutnya tahap analisis fisik, kimia dan hedonik sosis daging kalkun. Proses pembuatan sosis daging kalkun dilakukan dengan daging segar kalkun bagian dada dan paha dicuci, dipotong-potong dan digiling dengan alat blender. Daging hasil gilingan dicampurkan dengan filler, binder, dan bumbu-bumbu dengan menggunakan food processor sampai terbentuk adonan sosis. Adonan sosis dimasukkan ke dalam plastik segitiga lalu dilakukan proses selongsong dengan menggunak selongsong plastik polyamide food grade dengan panjang $10-15 \mathrm{~cm}$. Selanjutnya dikukus selama 45 menit dengan suhu $85-90^{\circ} \mathrm{C}$.

\section{Prosedur Analisis}

\section{Asam Lemak Tak Jenuh}

Langkah analisis asam lemak tak jenuh menggunakan alat Gas Chromatography (GC) (Jacoeb et al., 2020). Proses analisis asam lemak tak jenuh melalui beberapa tahapan diantaranya tahap ekstraksi, tahap pembuatan metil ester dan tahap analisis dengan Gas Chromatography (GC).

\section{Kolesterol}

Pengujian kolesterol dilakukan dengan menggunakan Liebermann - Burchard Colour Reaction (Astiana et al., 2015; Ningrumsari dan Herlinawati, 2019). Sampel sosis diekstraksi dengan menggunakan pelarut organik kloroform. Setiap ekstrak sampel sosis daging kalkun ditetesi dengan larutan metode Liebermann - Burchard yang terdiri dari perbandingan antara anhidrida asam asetat dan asam sulfat yaitu (3:1) yang dapat digunakan mengukur standar kolesterol. Panjang gelombang $(\lambda) 420 \mathrm{~nm}$ digunakan untuk membaca absorbansi pada alat spektrofotometri.

\section{Analisis Data}

Data asam lemak tak jenuh dan kolesterol dianalisis dengan menggunakan Microsoft Excel 2019 dan disajikan dalam bentuk diagram kemudian diuraikan secara deskriptif. 
Karakteristik Asam Lemak Tak Jenuh dan Kolesterol Sosis Daging Kalkun - Dwiloka, dkk Jurnal Pangan dan Agroindustri Vol. 9 No.3: 173-180, Juli 2021

\section{HASIL DAN PEMBAHASAN}

\section{Asam Lemak Tak Jenuh} pada Tabel 2.

Data rata-rata asam lemak tak jenuh sosis daging dada dan paha kalkun, dirujukkan Tabel 2. Asam Lemak Tak Jenuh Sosis Daging Kalkun

\begin{tabular}{lcc}
\multirow{2}{*}{ Jenis Asam Lemak } & \multicolumn{2}{c}{ Persentasi Asam Lemak Tak Jenuh } \\
\cline { 2 - 3 } & \multicolumn{2}{c}{ (\%) } \\
\hline Asam Palmitoleat $(\mathrm{C} 16: 1)$ & 0.36 & T2 \\
Asam Oleat (C18:1) & 22.54 & 0.34 \\
Asam Linoleat (C18:2) & 40.06 & 22.73 \\
Asam Linolenat (C18:3) & 0.51 & 37.39 \\
\hline Jumlah & 63.47 & 0.40 \\
\hline
\end{tabular}

Keterangan: $\mathrm{T} 1$ = Dada, T2 = Paha

Berdasarkan hasil pengujian asam lemak tak jenuh pada Tabel 2, sosis yang terbuat dari daging dada dan paha kalkun mengandung empat macam asam lemak tak jenuh yaitu oleat, linoleat, palmitoleat dan linolenat dengan jumlah persentase keempatnya lebih banyak pada sosis dada (63.47\%) dibandingkan sosis daging kalkun bagian paha $(60.86 \%)$. Sejalan dengan penelitian Zhang et al. (2013) bahwa daging dada memiliki tinggi kandungan asam lemak tak jenuh sehingga kandungan kolesterol lebih rendah. Rendahnya kolesterol pada daging kalkun menyebabkan asam lemak tak jenuh lebih tinggi dibanding jenis unggas lainnya. Faten et al. (2017) nilai nutrisi kalkun lebih tinggi dibandingkan jenis unggas lainnya. Kandungan kolesterol dalam produk hewani juga dipengaruhi oleh lemak intramuskuler. Peningkatan kadar lemak intramuskuler dalam daging dapat meningkatkan kandungan kolesterol.

Meningkatkan nilai gizi yang tinggi pada hasil olahan pangan, antara lain sosis daging kalkun, dengan cara menentukan nilai nutrisi produk yang memiliki konsentrasi kolesterol rendah, asam lemak tak jenuh yang tinggi, dan rendah asam lemak jenuh, dapat menjadi potensi untuk meningkatkan kesehatan tanpa mengurangi atau menghilangkan konsumsi produk olahan daging. Pernyataan Skiepko et al. (2016) bahwa profil asam lemak sangat penting untuk mengetahui kualitas produk hewani sehingga daging dada mengandung asam lemak jenuh dan asam lemak tak jenuh tunggal lebih rendah serta asam lemak tak jenuh dan asam lemak tak jenuh ganda lebih tinggi. Asam lemak tak jenuh terkandung dalam sosis daging kalkun terdiri dari asam lemak tak jenuh tunggal yaitu palmitoleat (C16:1) dan oleat (C18:1) serta asam lemak tak jenuh dengan ikatan ganda yaitu linoleate (C18:2) dan linolenat (C18:3). Kandungan palmitoleat pada potongan komersial karkas dada lebih tinggi dibandingkan paha. Igenbayev et al. (2019) menyatakan bahwa asam palmitoleat termasuk monounsaturated fatty acid (MUFA) yang banyak ditemukan dalam daging putih atau dada dibandingkan daging merah atau paha. Kandungan asam palmitoleat berpengaruh terhadap pencegahan penyakit kardiovaskuler, hepatic steatosi, cancer, diabetes dan obesitas. Kandungan asam oleat pada potongan komersial karkas dada dan paha kalkun tidak berbeda jauh serta lebih tinggi dibandingkan kandungan asam palmitoleat. Watson and De Meester, (2016) menyatakan bahwa asam oleat menyebabkan rendahnya kolesterol dalam tubuh dengan cara menurunkan kolesterol (LDL) dan meningkatkan kolesterol baik (HDL) dalam tubuh, mengakibatkan penurunan resiko penyakit stroke, dan tekanan darah tinggi. Asam linoleat dan asam linolenat tergolong ke dalam asam lemak tak jenuh dengan ikatan rangkap ganda. Kandungan linoleat dan linolenat lebih tinggi pada produk sosis kalkun dengan potongan komersial karkas dada dibandingkan paha. Eleroğlu et al. (2013) juga menyebutkan bahwa daging unggas bagian dada lebih banyak mengandung polyunsaturated fatty acids (PUFA) jenis linoleat (C18:2) dibandingkan linolenat (C18:3). Asam linoleat atau yang disebut dengan omega- 6 pada produk sosis juga dapat dipengaruhi oleh minyak nabati yang digunakan. Bahan pangan yang mengandung omega- 6 adalah kedelai, palm, dan bunga 
matahari sedangkan yang mengandung omega-3 terdapat pada kacang-kacangan dan ikan. Konsumsi produk yang mengandung asam lemak linoleat dapat mengurangi terjadinya penyakit jantung koroner. Asam linolenat sering disebut sebagai omega-3. Asam linolenat yang terdapat pada produk hewani terdiri dari dua jenis yaitu EPA dan DHA yang sangat penting bagi kesehatan tubuh. Pernyataan Alagawany et al. (2019) bahwa docosahexaenoic acid (DHA) dan eicosapentaenoic acid (EPA) bermanfaat untuk membantu dalam perkembangan janin, fungsi kardiovaskuler, mencegah terjadinya penyakit alzheimer, serta meningkatkan imunitas tubuh.

\section{Kolesterol}

Data rata-rata kandungan kolesterol sosis yang terbuat dari daging dada dan paha kalkun, berdasarkan pada Gambar 1 menyatakan sosis yang terbuat dari daging dada mengandung kolesterol $(88.5 \mathrm{mg} / \mathrm{kg}$ ) lebih rendah dibandingkan paha $(89.10 \mathrm{mg} / \mathrm{kg})$. Hal ini dikarenakan kandungan lemak daging paha yang tinggi dibanding dengan dada. Salma et al. (2016) bahwa jaringan otot dada mengandung kolesterol yang lebih rendah dibandingkan otot paha, hal ini dipengaruhi oleh kandungan lemak setiap potongan komersial karkas. Daging dada kalkun yang memiliki warna terang mengandung lemak yang lebih rendah dibandingkan daging paha yang memiliki warna yang gelap. Sesuai dengan Saygi et al. (2018) bahwa kadar lemak berbanding lurus dengan kadar kolesterol produk olahan daging, dimana semakin rendah kadar lemak maka menghasilkan jumlah kolesterol yang lebih rendah.

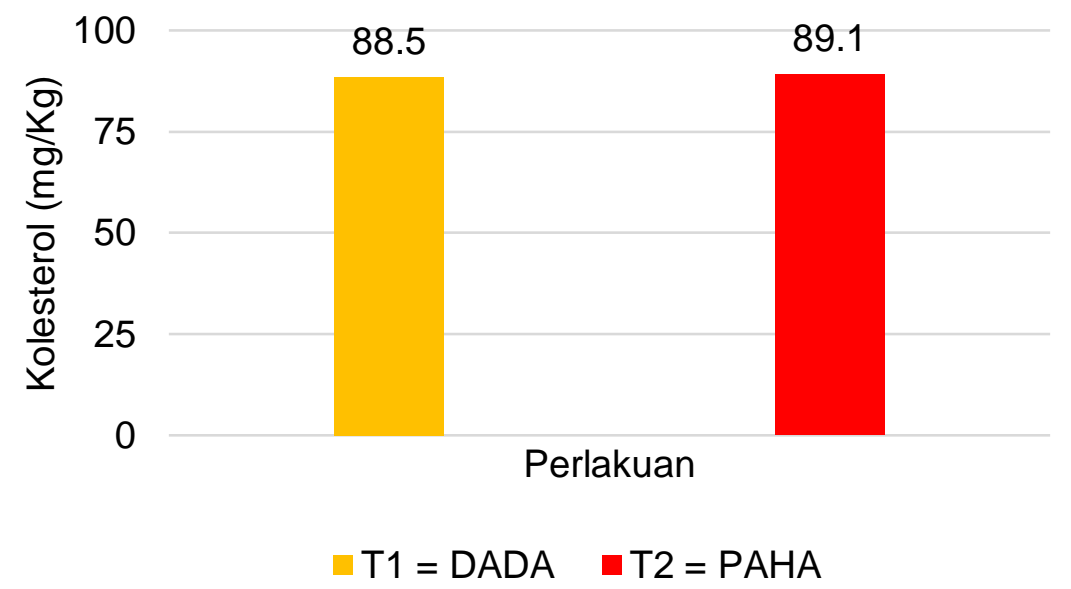

Gambar 1. Hasil Uji Kolesterol Sosis Daging Kalkun

Kadar kolesterol dalam produk olahan daging menjadi hal penting pada penerimaan konsumen dalam segi kesehatan. Proses pemasakan dapat mempengaruhi kadar kolesterol dalam sosis. Pemanasan selama proses pemasakan menyebabkan penurunan kadar kolesterol dalam produk karena kolesterol akan larut bersama air yang terlepas dari produk (Aisyah et al., 2019). Kandungan kolesterol dalam produk olahan daging akan mengalami oksidasi selama pemasakan, sebagaimana pendapat Bauer et al. (2014) yang menyatakan bahwa peningkatan suhu tinggi selama proses pemasakan dapat menyebabkan terjadinya oksidasi kolesterol. Kolesterol sangat penting bagi kesehatan tubuh manusia, namun apabila berlebihan dalam tubuh dapat dampak negatif bagi kesehatan. Sebagian kecil kolesterol dalam tubuh berasal dari produk makanan yang dikonsumsi sedangkan sebagian besar kolesterol disintesis oleh tubuh manusia. Peningkatan HDL dalam tubuh dapat membantu mengeluarkan kelebihan kolesterol yang dapat menghambat pembuluh darah. Zulhaidar et al. (2017) menyatakan HDL tergolong lipoprotein yang memiliki densitas yang tinggi dengan kandungan protein yang lebih tinggi serta rendah lemak yang dapat menyerap kolesterol Low Density Lipoprotein (LDL) dalam darah. Kandungan kolesterol dalam sosis berhubungan profil asam lemak. Profil asam lemak diantaranya asam lemak jenuh yang tidak punya ikatan 
rangkap dan asam lemak tak jenuh yang punya ikatan rangkap pada rantai molekulnya yang dapat ditemukan pada produk olahan makanan yang bersumber dari hewani sehingga peningkatan konsumsi asam lemak tak jenuh dapat meningkatkan HDL dalam tubuh. Aksoy et al. (2019) menyatakan konsumsi makanan yang mengandung asam lemak tak jenuh yang berlebih dapat mengurangi kolesterol jahat dalam tubuh begitu juga makanan yang mengandung asam lemak jenuh yang berlebih dapat menambah kolesterol jahat dalam tubuh. Kandungan kolesterol produk makanan dalam tubuh akan diserap oleh usus dan dibawa oleh jaringan lemak serta dihidrolisis dengan bantuan enzim lipoprotein protease lalu disimpan dalam hati. Hal ini didukung oleh Azimifar et al. (2014) menyatakan fungsi hati dalam tubuh yaitu mengatur kolesterol dalam tubuh. Tubuh seseorang memiliki kadar kolesterol normal dalam tubuh dengan kisaran 160-200 mg/dL sehingga apabila melebihi dari batas normal dapat mengakibat penyakit hiperkolesterolemia.

\section{SIMPULAN}

Berdasarkan hasil penelitian dapat ditarik kesimpulan bahwa perbedaan potongan komersial karkas dada dan paha berpengaruh terhadap karakteristik asam lemak tak jenuh dan kolesterol sosis daging kalkun. Asam lemak tak jenuh sosis kalkun yang terbuat dari daging bagian dada lebih tinggi dibandingkan paha serta kandungan kolesterol sosis kalkun yang terbuat dari daging dada lebih rendah dibandingkan paha.

\section{DAFTAR PUSTAKA}

Aisyah, N. F., Aisyah, N., Kusuma, T. S., \& Widyanto, R. M. (2019). Profil asam lemak jenuh dan tak jenuh serta kandungan kolesterol nugget daging kelinci new zealand white (Oryctolagus cuniculus). Jurnal Al-Azhar Indonesia Seri Sains dan Teknologi, 5(2), 100. https://doi.org/10.36722/sst.v5i2.356

Aksoy, Y., Çiçek, Ü., Sen, U., Åžirin, E., Ugurlu, M., Önenç, A., Kuran, M., \& Ulutas, Z. (2019). Meat production characteristics of Turkish native breeds: II. meat quality, fatty acid, and cholesterol profile of lambs. Archives Animal Breeding, 62(1), 41-48. https://doi.org/10.5194/aab-62-41-2019

Alagawany, M., Elnesr, S. S., Farag, M. R., Abd El-Hack, M. E., Khafaga, A. F., Taha, A. E., Tiwari, R., lqbal, Y. M., Bhatt, P., Kumas, K. S., \& Dhama, K. (2019). Omega-3 and Omega-6 Fatty Acids in Poultry Nutrition: Effect on Production Performance and Health . Animals, 9(8), 573. https://doi.org/10.3390/ani9080573

Astiana, I., Nurjanah, Suwandi, R., Ashory Suryani, A., \& Hidayat, T. (2015). Pengaruh penggorengan belut sawah (Monopterus albus) terhadap komposisi asam amino, asam lemak, kolesterol dan mineral. DEPIK, 4(1), 49-57. https://doi.org/10.13170/depik.1.1.2366

Azimifar, S. B., Nagaraj, N., Cox, J., \& Mann, M. (2014). Cell-type-resolved quantitative proteomics of murine liver. Cell Metabolism, 20(6), 1076-1087. https://doi.org/10.1016/j.cmet.2014.11.002

Bauer, L. C., De Santana, D. A., Dos Macedo, M. S., Torres, A. G., De Souza, N. E., \& Simionato, J. I. (2014). Method validation for simultaneous determination of cholesterol and cholesterol oxides in milk by RP-HPLC-DAD. Journal of the Brazilian Chemical Society, 25(1), 161-168. https://doi.org/10.5935/0103-5053.20130283

Eleroğlu, H., Yıldırım, A., Işıklı, N. D., Şekeroğlu, A., \& Duman, M. (2013). Comparison of Meat Quality and Fatty Acid Profile in Slow-Growing Chicken Genotypes Fed Diets Supplemented with Origanum Vulgare or Melissa Officinalis Leaves Under the Organic System. Italian Journal of Animal Science, 12(3), 395-403. https://doi.org/10.4081/ijas.2013.e64

Faten, S. H., Hassan, M. A., Nabila, I. E., \& Tereza, H. A. (2017). Rancidity as Lipolytic Index in Poultry Meat Cuts. Benha Veterinary Medical Journal, 33(2), 343-350. https://doi.org/10.21608/bvmj.2017.30498 
Gálvez, F., Dominguez, R., Pateiro, M., Carballo, J., Tomasevic, I., \& Lorenzo, J. M. (2018). Effect of gender on breast and thigh turkey meat quality. British Poultry Science. 408-415 https://doi.org/10.1080/00071668.2018.1465177

Igenbayev, A., Nurgazezova, A., Okuskhanova, E., Rebezov, Y., Kassymov, S., Nurymkhan, G., Tazeddinova, D., \& Rebezov, M. I. (2019). Fatty Acid 78 JWPR Journal of World's Poultry Research. Scienceline Publication J. World Poult. Res, 9(2), 78-81. https://doi.org/10.36380/jwpr.2019.9

Jacoeb, A. M., Nurjanah, Hidayat, T., \& Perdiansyah, R. (2020). Komposisi kimia dan profil asam lemak ikan layur aegar penyimpanan suhu dingin. Jurnal Pengolahan Hasil Perikanan Indonesia, 23(1), 147-157. https://doi.org/10.17844/jphpi.v23i1.31057

Mait, Y. S., Rompis, J. E. G., Tulung, B., Laihad, J., \& Londok, J. J. M. R. (2019). Pengaruh pembatasan pakan dan sumber serat kasar berbeda terhadap bobot hidup, bobot karkas dan potongan komersial karkas ayam broiler strain lohman. Jurnal Zootec, 39(1), 134145. https://doi.org/10.35792/zot.39.1.2019.23810

Ningrumsari, I., \& Herlinawati, L. (2019). Peranan Lactobacillus acidophilus dalam pakan terfermentasi untuk meningkatkan kualitas daging ayam broiler (protein, kolesterol). Jurnal Pertanian, 10(2), 93-101. https://doi.org/10.30997/jp.v10i2.1954

Oktasari, R., Diasari, I., \& Susilowati, S. (2020). Pengaruh lama perendaman dalam berbagai konsentrasi sari buah asam jawa (Tamarindus indika L.) terhadap WHC dan pH daging kalkun. Jurnal Rekasatwa Peternakan, 3(1), 84-88.

Salma, A. R., Shamim, A., Khan, S. H., \& Anjum, M. A. (2016). A comparative study on quality, proximate composition and cholesterol content of eggs and meat in Fayoumi and commercial White Leghorn chickens. Cogent Food \& Agriculture, 2(1), 1-7. https://doi.org/10.1080/23311932.2016.1195539

Saygi, D., Ercoşkun, H., \& Şahin, E. (2018). Hazelnut as functional food component and fat replacer in fermented sausage. Journal of Food Science and Technology, 55(9), 33853390. https://doi.org/10.1007/s13197-018-3129-7

Septianggi, F. N., Mulyati, T., \& Sulistya, H., K. (2013). Hubungan asupan lemak dan asupan kolesterol dengan kadar kolesterol total pada penderita jantung koroner rawat jalan di RSUD Tugurejo Semarang. Jurnal Gizi, 2(2), 13-20. https://doi.org/10.26714/JG.2.2.2013.\%P

Skiepko, N., Chwastowska-Siwiecka, I., Kondratowicz, J., \& Mikulski, D. (2016). Fatty acid profile, total cholesterol, vitamin content, and TBARS value of Turkey breast muscle cured with the addition of lycopene. Poultry Science, 95(5), 1182-1190. https://doi.org/10.3382/ps/pew005

Sofiana, A. (2012). Penambahan tepung protein kedelai sebagai bahan pengikat pada sosis sapi. Jurnal IImiah IImu-IImu Peternakan Universitas Jambi, 15(1), 1-7. https://doi.org/10.22437/jiiip.v15i1.1512

Straková, E., Suchý, P., Karásková, K., Jámbor, M., \& Navrátil, P. (2011). Comparison of nutritional values of pheasant and broiler chicken meats. Acta Veterinaria Brno, 80(4), 373-377. https://doi.org/10.2754/avb201180040373

Suloi, A. N. F., Budyghifari, L., Dwi Arista, S. S., \& Laga, A. (2019). Pengaruh konsentrasi kentos kelapa terhadap degradasi lemak daging ayam. Canrea Journal: Food Technology, Nutritions, and Culinary Journal, 2(1), 38-43. https://doi.org/10.20956/canrea.v2i1.176

Watson, R. R., \& De Meester, F. (2016). Handbook of cholesterol (R. R. Watson \& F. De Meester, eds.). The Netherlands: Wageningen Academic Publishers. https://doi.org/10.3920/978-90-8686-821-6

Widiatmoko, F., Kurtini, T., \& Nova, K. (2014). Pengaruh umur induk terhadap fertilitas, susut tetas, daya tetas, dan bobot tetas telur kalkun. Jurnal IImiah Peternakan Terpadu, 2(1), 11-15. https://doi.org/10.23960/JIPT.V2I1.P\%P

Widiyawati, I., Sjofjan, O., \& Adli, D. N. (2020). Peningkatan kualitas dan persentase karkas ayam pedaging dengan subtitusi bungkil kedelai menggunakan tepung biji asam (Tamarindus indica L) fermentasi. Jurnal Nutrisi Ternak Tropis, 3(1), 35-40. 
https://doi.org/10.21776/ub.jnt.2020.003.01.7

Yuliantini, E., Sari, A. P., \& Nur, E. (2016). Hubungan asupan energi, lemak dan serat dengan rasio kadar kolesterol total - HDL. Penelitian Gizi Dan Makanan (The Journal of Nutrition and Food Research), 38(2), 139-147. https://doi.org/10.22435/pgm.v38i2.5543.139-147

Zhang, Z. F., Zhou, T. X., \& Kim, I. H. (2013). Effects of dietary olive oil on growth performance, carcass parameters, serum characteristics, and fatty acid composition of breast and drumstick meat in broilers. Asian-Australasian Journal of Animal Sciences, 26(3), 416422. https://doi.org/10.5713/ajas.2012.12486

Zulhaidar, M. H., Saraswati, T. R., \& Tana, S. (2017). Kadar High Density Lipoprotein (HDL) telur puyuh jepang (Coturnix japonica L.) setelah pemberian tepung kunyit (Curcuma longa L.) pada pakan. Buletin Anatomi Dan Fisiologi, 2(1), 67-71. https://doi.org/10.14710/baf.2.1.2017.67-71 